\title{
Effects of low-power light therapy on wound healing: LASER x LED*
}

\author{
Maria Emília de Abreu Chaves ${ }^{1}$ \\ André Costa Cruz Piancastelli ${ }^{3}$
}

\author{
Angélica Rodrigues de Araújo² \\ Marcos Pinotti ${ }^{1}$
}

DOI: http://dx.doi.org/10.1590/abd1806-4841.20142519

\begin{abstract}
Several studies demonstrate the benefits of low-power light therapy on wound healing. However, the use of LED as a therapeutic resource remains controversial. There are questions regarding the equality or not of biological effects promoted by LED and LASER. One objective of this review was to determine the biological effects that support the use of LED on wound healing. Another objective was to identify LED's parameters for the treatment of wounds. The biological effects and parameters of LED will be compared to those of LASER. Literature was obtained from online databases such as Medline, PubMed, Science Direct and Scielo. The search was restricted to studies published in English and Portuguese from 1992 to 2012. Sixty-eight studies in vitro and in animals were analyzed. LED and LASER promote similar biological effects, such as decrease of inflammatory cells, increased fibroblast proliferation, stimulation of angiogenesis, granulation tissue formation and increased synthesis of collagen. The irradiation parameters are also similar between LED and LASER. The biological effects are dependent on irradiation parameters, mainly wavelength and dose. This review elucidates the importance of defining parameters for the use of light devices.
\end{abstract}

Keywords: Light; Phototherapy; Wound healing

\section{INTRODUCTION}

A wound is characterized by the interruption on the continuity of a body tissue. It can be caused by any type of physical, chemical and mechanical trauma or triggered by a medical condition. ${ }^{1}$ Cutaneous wounds are relatively common in adults and their incidence seems to increase in parallel with the advances in life expectancy in the population. ${ }^{2}$

The therapeutic approach to wound healing consists of preventive measures such as health professional continuing education, family counseling and guidelines to a proper patient nutrition. The use of medicinal plants, administration of essential fatty acids, calcium alginate, antiseptics and degerming products, activated carbon, semi-permeable films, biological collagen, cell growth factors, hydropolymer, hydrogel and hydrocolloid substances, proteolytic enzymes, sulfadiazine silver, gauze dressings, bandages for skin protection and compression are also advocated. ${ }^{3}$ Physical treatments such as therapeutic ultrasound and electrotherapy are cited likewise in the literature as important adjuncts in wound management. ${ }^{4,5}$ These therapies seem to be advantageous but they have limitations and do not always achieve satisfactory results.

Wounds that are difficult to heal represent a serious public health problem. The lesions severely affect the quality of life of individuals due to decreased mobility and substantial loss of productivity; they can also cause emotional damage and contribute to increase the burden of public expenditures in healthcare. ${ }^{6}$

The need to care for a population with poorly healing wounds is a growing challenge that requires innovative strategies. An approach that stands out in the treatment of these lesions is low-power light therapy, promoted by light devices such as LASER (Light Amplification by Stimulated Emission of Radiation) and LED (Light Emitting Diode).

Received on 06.02.2013.

Approved by the Advisory Board and accepted for publication on 29.07.2013.

* Work performed at the Bioengineering Laboratory at Universidade Federal de Minas Gerais (UFMG) - Belo Horizonte (MG), Brazil.

Conflict of interest: None

Financial Support: None

Universidade Federal de Minas Gerais (UFMG) - Belo Horizonte (MG), Brazil

Pontifícia Universidade Católica de Minas Gerais (PUC Minas) - Belo Horizonte (MG), Brazil.

Serviço de Dermatologia do Hospital da Polícia Militar (HPM) de Minas Gerais - Belo Horizonte (MG), Brasil. 
The therapeutic benefits of LASER light in the treatment of wounds have been reported since the 1960s and those of LED light only since the 1990s ${ }^{7,8}$ However, many of the results described show inconsistency, mainly due to methodology bias or lack of standardization in the studies. Furthermore, the use of LED as a therapeutic resource remains controversial. There are questions regarding the equality or not of biological and therapeutic effects promoted by LED and LASER resources, but also regarding the appropriate parameters to each of these light sources.

This study aimed to determine, through a literature review: 1 - the biological effects that support the use of light sources such as LED in the treatment of wounds and 2 - the light parameters (wavelength and dose) suitable for the treatment of wounds with LED light sources. The biological effects and light parameters of LED will be compared to those of LASER in order to verify the similarity (or not) regarding wound treatment.

\section{MATERIALS AND METHODS}

A literature search was performed in Medline, PubMed, SciELO and Science Direct databases. The literature search was restricted to studies published in English and Portuguese in the period of 1992-2012. The keywords used were "low level laser therapy", "laser", "light emitting diode", "LED", "phototherapy", "wound healing", "fibroblast", "collagen" and "angyogenesis" combined with each other.

\section{RESULTS}

Sixty-eight studies were analyzed, including 48 on LASER light, 14 related to LED light and 6 for both types of light (Tables 1 to 3 ). According to data presented on table 1,16 of the 48 studies on the effects of LASER light were in vitro and 32 were performed in animals. ${ }^{9-56}$ The use of different wavelengths (532-1064 nm) was verified, with the most utilized spectral range being between 632.8 and $830 \mathrm{~nm}$. Doses ranging from 0.09 to $90 \mathrm{~J} / \mathrm{cm}^{2}$ were used, predominating the values from 1 to $5 \mathrm{~J} / \mathrm{cm}^{2}$. One study did not cite the dose value used. ${ }^{48}$ The biological effects promoted were reduction of inflammatory cells, increased proliferation of fibroblasts, stimulation of collagen synthesis, angiogenesis inducement and granulation tissue formation. It was noted in a study that the dose of 4 $\mathrm{J} / \mathrm{cm}^{2}$ was more effective than $8 \mathrm{~J} / \mathrm{cm}^{2} \cdot{ }^{14}$ Furthermore, doses of 10 and $16 \mathrm{~J} / \mathrm{cm}^{2}$ promoted inhibitory effects. ${ }^{20,25,29,34}$

Eight of the 14 studies on the effects of LED light were in vitro studies and 6 performed in animals, as shown in table $2 .^{57-70}$ Wavelengths ranging 456-880 $\mathrm{nm}$ were used, with spectral range from 627 to $670 \mathrm{~nm}$ predominating. Doses ranged from 0.1 to $10 \mathrm{~J} / \mathrm{cm}^{2}$, and $4 \mathrm{~J} / \mathrm{cm}^{2}$ was the predominant dose. However, not all studies reported the dose applied..$^{64,66,67,68}$ Biological effects observed were reduction of inflammatory cells, increased fibroblast proliferation, collagen synthesis, stimulation of angiogenesis and granulation tissue formation, these being similar to the ones observed in studies with LASER.

Table 3 shows six studies comparing the biological effects of LASER and LED lights. ${ }^{71-76}$ Two of the studies were in vitro and 4 were performed in rats. It has been noticed that wavelengths varied from 460 to $950 \mathrm{~nm}$, with the range of $630-790 \mathrm{~nm}$ being the most utilized both in LASER and LED studies. Doses ranging from 0.1 to $10 \mathrm{~J} / \mathrm{cm}^{2}$ were used, with predominance of doses up to $5 \mathrm{~J} / \mathrm{cm}^{2}$. All studies reported similar effects between LASER and LED, such as increased fibroblast proliferation and stimulation of angiogenesis.

\section{DISCUSSION}

Since the introduction of photobiomodulation in healthcare, the effectiveness and applicability of light resources for the treatment of skin wounds have been extensively investigated both in vitro and in vivo. Nevertheless, the biological mechanisms that support the actions of low intensity light in tissues are still not clearly elucidated. While some studies report an increase in cellular proliferation of several cell types including fibroblasts, endothelial cells and keratinocytes, conflicting results about the clinical benefits of using light on skin wounds are found in the literature.

The way light interacts with the biological tissues will depend on the characteristics and parameters of light devices, mainly the wavelength and dose, and also the optical properties of the tissue.

Regarding the characteristics of light devices, LASER consists of a resonant optical cavity and different types of active media such as solid, liquid or gaseous materials, in which processes of light generation occur through the passage of an electric current. ${ }^{77}$ Potency in the range of $10^{-3}$ to $10^{-1} \mathrm{~W}$, wavelength from 300 to $10,600 \mathrm{~nm}$, pulse frequency from 0 (continuous emission) to $5,000 \mathrm{~Hz}$, pulse duration and pulse interval from 1 to 500 milliseconds, total radiation from $10-3000$ seconds, intensity between $10^{-2}$ and $10^{0}$ $\mathrm{Wcm}^{-1}$ and dose from $10^{-2}$ to $10^{2} \mathrm{Jcm}^{-2}$ characterized LASER as a low potency device. ${ }^{78}$

On the other hand, LED is a diode formed by p-n junctions (p-positive, n-negative) that, when directly polarized, causes electrons to cross the potential barrier and recombine with holes within the device. After the spontaneous recombination of electron-hole pairs, the simultaneous emission of photons occurs. The physical mechanism by which LED emits light is spontaneous light emission. The light-emitting 
TABLE 1: Biological effects of LASER light on cutaneous wounds

\begin{tabular}{|c|c|c|c|c|}
\hline Study & Model & Wavelength (nm) & Dose $(J / \mathrm{cm} 2)$ & Biological effects \\
\hline & \multirow{3}{*}{ In vitro } & 632 & $9 ; 15 ; 30 ; 60 ; 90$ & \multirow{3}{*}{+} \\
\hline \multirow[t]{2}{*}{ Lubart et al. ${ }^{9}$} & & & & \\
\hline & & 780 & $7 ; 18 ; 36 ; 72$ & \\
\hline Yu et al. ${ }^{10}$ & Mouse & 630 & 5 & + \\
\hline Almeida-Lopes et al..$^{11}$ & In vitro & $670 ; 692 ; 780 ; 786$ & 2 & + \\
\hline Reddy et al..$^{12}$ & Rat & 632,8 & 1 & + \\
\hline Pereira et al. ${ }^{13}$ & In vitro & 904 & $3 ; 4 ; 5$ & + \\
\hline Medrado et al..$^{14}$ & Rat & 670 & $4 ; 8$ & + \\
\hline Pugliese et al..$^{15}$ & Rat & 670 & $4 ; 8$ & + \\
\hline Reddy $^{16}$ & Rat & 904 & 1 & + \\
\hline Byrnes et al. ${ }^{17}$ & Rat & 632.8 & $4 ; 5 ; 7.2$ & + \\
\hline Nascimento et al..$^{18}$ & Rat & $670 ; 685$ & 10 & + \\
\hline Ribeiro et al. ${ }^{19}$ & Rat & 632.8 & 1 & + \\
\hline Hawkins and Abrahamse $\mathrm{e}^{20}$ & In vitro & 632.8 & $0.5 ; 2.5 ; 5 ; 10$ & + \\
\hline Maiya et al. ${ }^{21}$ & Rat & 632.8 & 4.8 & + \\
\hline Moore et al. ${ }^{22}$ & In vitro & $625-675 ; 810$ & 10 & + \\
\hline Poon et al..$^{23}$ & In vitro & 532 & 0.8 & + \\
\hline Carvalho et al..$^{24}$ & Rat & 632.8 & 4 & + \\
\hline Hawkins and Abrahamse ${ }^{25}$ & In vitro & 632.8 & $2.5 ; 5 ; 16$ & + \\
\hline Rabelo et al. ${ }^{26}$ & Rat & 632.8 & 10 & + \\
\hline Araújo et al. ${ }^{27}$ & Mouse & 632.8 & 1 & + \\
\hline Hawkins and Abrahamse $e^{28}$ & In vitro & $632.8 ; 830$ & 5 & + \\
\hline Houreld and Abrahamse ${ }^{29}$ & In vitro & 632.8 & $5 ; 16$ & + \\
\hline Mirzaei et al..$^{30}$ & In vitro & 632.8 & $0.09 ; 1 ; 4$ & + \\
\hline Rezende et al..$^{31}$ & Rat & 830 & 1,$3 ; 3$ & + \\
\hline Viegas et al. ${ }^{32}$ & Rat & $685 ; 830$ & 4 & + \\
\hline Yasukawa et al. ${ }^{33}$ & Rat & 632.8 & $2.09 ; 4.21$ & + \\
\hline Houreld and Abrahamse ${ }^{34}$ & In vitro & $632.8 ; 830$ & $5 ; 16$ & + \\
\hline Medrado et al..$^{35}$ & Rat & 670 & 4 & + \\
\hline Meireles et al. ${ }^{36}$ & Rat & $660 ; 780$ & 20 & + \\
\hline Reis et al..$^{37}$ & Rat & 670 & 4 & + \\
\hline Gungormus and $\mathrm{Akyol}^{38}$ & Rat & 808 & 10 & + \\
\hline Skopin and Molitor ${ }^{39}$ & In vitro & 980 & $3.1-14.4$ & + \\
\hline Carvalho et al..$^{40}$ & Rat & 660 & 4 & + \\
\hline \multirow[t]{3}{*}{ Chung et al. ${ }^{41}$} & Mouse & 660 & $1.9-2.5$ & + \\
\hline & & & $3.7-5.0$ & \\
\hline & & & $7.4-10$ & \\
\hline Gonçalves et al. ${ }^{42}$ & Rat & 830 & $30 ; 60$ & + \\
\hline \multirow[t]{2}{*}{ Gonçalves et al..$^{43}$} & Rat & 830 & $30 ; 60$ & + \\
\hline & & 904 & 4 & \\
\hline Guirro et al. ${ }^{44}$ & Rat & 670 & $4 ; 7$ & + \\
\hline Houreld and Abrahamse ${ }^{45}$ & In vitro & $632.8 ; 830$ & 5 & + \\
\hline Lacjakova et al. ${ }^{46}$ & Rat & 670 & 5 & + \\
\hline Medeiros et al..$^{47}$ & Rat & 655 & 12 & + \\
\hline Hussein et al. ${ }^{48}$ & Rabbit & 890 & --------- & + \\
\hline Silveira et al. ${ }^{49}$ & Rat & $660 ; 904$ & $1 ; 3$ & + \\
\hline \multirow[t]{2}{*}{ Weng et al..$^{50}$} & In vitro & 532 & 35 & + \\
\hline & & 1064 & 1.2 & \\
\hline Basso et al..$^{51}$ & In vitro & 780 & $0.5 ; 1.5 ; 3 ; 5 ; 7$ & + \\
\hline Crisan et al..$^{52}$ & In vitro & $830 ; 980$ & 5.5 & + \\
\hline Dawood and Salman ${ }^{53}$ & Mouse & 650 & $38.2 ; 57.3$ & + \\
\hline Fahimipour et al. ${ }^{54}$ & Mouse & $632.8 ; 830$ & $4 ; 7.5$ & + \\
\hline Gonçalves et al..$^{55}$ & Rat & 830 & $30 ; 90$ & + \\
\hline Nunez et al..$^{56}$ & Rat & 660 & $1 ; 4$ & + \\
\hline
\end{tabular}


TABLE 2: Biological effects of LED light on cutaneous wounds

\begin{tabular}{|c|c|c|c|c|}
\hline Study & Model & Wavelength (nm) & Dose (J/cm2) & Biological effects \\
\hline Whelan et al. ${ }^{57}$ & In vitro & $670 ; 728 ; 880$ & $4 ; 8$ & + \\
\hline Vinck et al..$^{58}$ & In vitro & 570 & 0.1 & + \\
\hline Weiss et al..$^{59}$ & In vitro & 590 & 0.1 & + \\
\hline Huang et al. ${ }^{60}$ & In vitro & 630 & $1 ; 2$ & + \\
\hline Lanzafame et al. ${ }^{61}$ & Mouse & 670 & 5 & + \\
\hline Agnol et al..$^{62}$ & Rat & 640 & 6 & + \\
\hline Tada et al. ${ }^{63}$ & In vitro & 627 & $1 ; 2 ; 4 ; 8 ; 10$ & + \\
\hline Komine et al. ${ }^{64}$ & In vitro & 627 & 4 & + \\
\hline Meyer et al..$^{65}$ & Rat & $\begin{array}{l}515-525 \\
620-630\end{array}$ & -------- & + \\
\hline Sousa et al. ${ }^{66}$ & Rat & $460 ; 530 ; 700$ & 10 & + \\
\hline Adamskaya et al. ${ }^{67}$ & Rat & $470 ; 629$ & -------- & + \\
\hline Lim et al. ${ }^{68}$ & In vitro & 635 & -------- & + \\
\hline Cheon et al. ${ }^{69}$ & Rat & $470 ; 525 ; 633$ & -ב----- & + \\
\hline Fushimi et al. ${ }^{70}$ & In vitro & $456 ; 518 ; 638$ & $0.2 ; 0.3 ; 0.6$ & + \\
\hline
\end{tabular}

TABLE 3: Biological effects of LED and LASER light on cutaneous wounds

\begin{tabular}{|c|c|c|c|c|c|}
\hline Study & Model & Type of light & Wavelength (nm) & Dose (J/cm2) & Biological effects \\
\hline Vinck et al. ${ }^{70}$ & In vitro & $\begin{array}{l}\text { LASER } \\
\text { LED }\end{array}$ & $\begin{array}{l}830 \\
570 \\
660 \\
950\end{array}$ & $\begin{array}{l}1 \\
0.1 \\
0.53 \\
0.53\end{array}$ & + \\
\hline Corazza et al..$^{71}$ & Rat & $\begin{array}{l}\text { LASER } \\
\text { LED }\end{array}$ & $\begin{array}{l}660 \\
635\end{array}$ & $\begin{array}{l}5 \\
20\end{array}$ & + \\
\hline Volpato et al. ${ }^{72}$ & In vitro & $\begin{array}{l}\text { LASER } \\
\text { LED }\end{array}$ & $\begin{array}{l}660 \\
780 \\
637\end{array}$ & $\begin{array}{l}4 ; 8 \\
5 ; 10 \\
4 ; 8\end{array}$ & + \\
\hline Nishioka et al..$^{73}$ & Rat & $\begin{array}{l}\text { LASER } \\
\text { LED }\end{array}$ & $\begin{array}{l}660 \\
630\end{array}$ & 5 & + \\
\hline Sampaio et al. ${ }^{74}$ & Rat & $\begin{array}{l}\text { LASER } \\
\text { LED }\end{array}$ & $\begin{array}{l}660 \\
700\end{array}$ & 10 & + \\
\hline Sousa et al. ${ }^{75}$ & Rat & $\begin{array}{l}\text { LASER } \\
\text { LED }\end{array}$ & $\begin{array}{l}660 ; 790 \\
460 ; 530 ; 700\end{array}$ & 10 & + \\
\hline
\end{tabular}

diodes convert the electrical current in a light spectrum, a process called electroluminescence. ${ }^{79}$ LEDs usually operate with outputs in the range of milliwatts and therefore are usually set up on small chips or connected to small light bulbs. ${ }^{80}$

The variable characteristics and parameters of light devices is one of the factors that complicate the interpretation of research results about the effects of low intensity light on skin wounds. As observed in this study, there is discordance between the types of light and parameters used in studies. This fact may limit the decision-making process regarding the role of light in treating wounds since photobiomodulator effects are parameter-dependent.
Energy absorption is the primary mechanism that allows light from LASER or LED to produce biological effects in the tissue. Light absorption is dependent on wavelength and the main tissue chromophores (hemoglobin and melanin) strongly absorb wavelengths shorter than $600 \mathrm{~nm}$. For these reasons, there is a therapeutic window in the optical spectral range of red and near infrared, wherein the efficiency of light penetration in the tissue is maximum (Figure 1). ${ }^{81}$

Fifty-nine of the 68 studies reviewed applied LASER or LED inside the optical therapeutic window and 9 applied them in the range of blue or green, and even so biological effects were observed. Although light in the blue and green wavelengths range can 


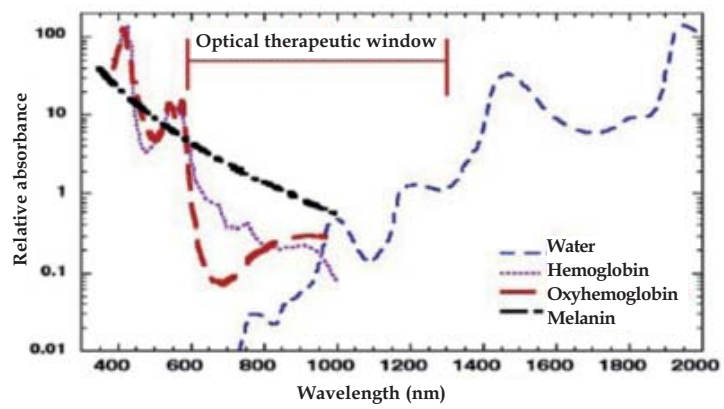

Source: Schindl A, et al. 2000.

Figure 1: Optical therapeutic window

achieve significant effects in cells, the use of low power light in animals and humans involves almost exclusively light in red and near infrared wavelengths. ${ }^{81}$ Historical issues, mainly cost and availability may be related to this fact.

As noted in Tables 1, 2 and 3 studies applied LASER or LED with doses around 0.09 to $90 \mathrm{~J} / \mathrm{cm}^{2}$. The most significant biological effects were seen with predominant dose values, i.e. up to $5 \mathrm{~J} / \mathrm{cm}^{2}$, which are within the Arndt-Schultz curve (Figure 2). According to Sommer et al, very low doses do not promote biological effects, while higher doses result in inhibition of cellular functions.$^{82}$ The energetic state of the cell, i.e. the physiological condition of the tissue in treatment is therefore critical to determine which dose to use.

The mechanism of light action on the cellular level that supports its biological effects is based on photobiological reactions. A photobiological reaction involves the absorption of a specific wavelength of light by photoreceptor molecules. ${ }^{83}$

There is evidence that wavelengths in the spectral range from red to near infrared are absorbed by cytochrome c oxidase. ${ }^{83,84}$ In the study by Karu and Kolyakov action spectra of monochromatic light from

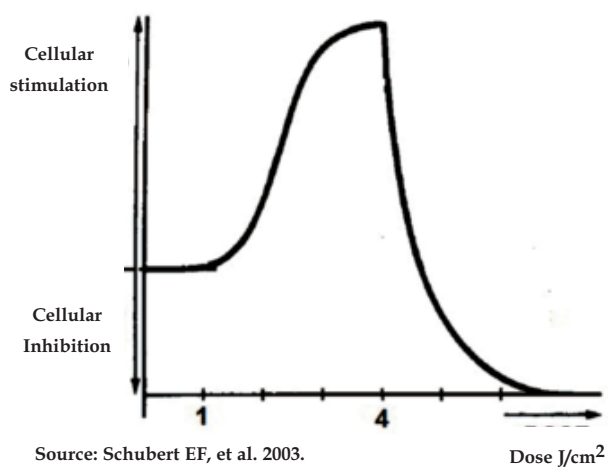

FIGURE 2: Arndt-Schultz Curve
580 to $860 \mathrm{~nm}$ were analyzed..$^{85}$ The authors noted four active spectral regions, two in the red range (peaks from 613.5 to $623.5 \mathrm{~nm}$ and 667.5 to $683.7 \mathrm{~nm}$ ) and two infrared (peaks from 750.7 to $772,3 \mathrm{~nm}$ and 812.5 to $846.0 \mathrm{~nm}$ ). In addition, they also observed the absorption by cytochrome c oxidase in these four bands. The authors concluded that cytochrome c oxidase could absorb light in different spectral bands (red and near infrared), probably in the binuclear centers $\mathrm{CuA}$ and $\mathrm{CuB}$ (oxidized forms).

Photobiological reactions can be classified into primary and secondary. Primary reactions derive from the interaction between photons and the photoreceptor, and they are observed in a few seconds or minutes after the irradiation of light. On the other hand, secondary reactions are effects that occur in response to primary reactions, in hours or even days after the irradiation procedure. . $^{84,86}$

The primary reactions of light action on photoreceptors are not yet clearly established, but there are some hypotheses. After the absorption of light in the irradiated wavelength, cytochrome c oxidase displays an electronically excited status, from which it alters its redox status and causes the acceleration of electron transfer in the respiratory chain. ${ }^{87}$ Another hypothesis is that a part of the electronically excited status energy is converted into heat, causing a localized and transient heating in photoreceptors. ${ }^{88} \mathrm{~A}$ third assumption would be that when enabling the flow of electrons in the respiratory chain by light irradiation, an increase in the production of superoxide anion can be expected ${ }^{89} \mathrm{~A}$ fourth reaction formula assumes that porphyrins and flavoproteins absorb photons and generate reactive species of singlet oxygen. ${ }^{90}$ It has also been proposed that light can reverse cytochrome c oxidase inhibition through nitric oxide and thereby increase the rate of respiration..$^{91}$

The mechanism of secondary photobiological reactions is determined by transduction (energy transfer from one system to another) and photosignal amplification leading to photoresponse. This means that effects derived from primary reactions are amplified and transmitted to other parts of the cell, resulting in physiological effects such as alterations in cell membrane permeability with changes in intracellular calcium levels, increased cellular metabolism, DNA and RNA syntheses, fibroblast proliferation, activation of T lymphocytes, macrophages and mast cells, increased synthesis of endorphins and decreased bradykinin..$^{83}$

Secondary reactions are responsible for the connection between response to light action by photoreceptors located inside the mitochondria and the effects located in the nucleus or different phenomena in other cell components. This process makes it possi- 
ble to apply a very small amount of light to produce clinically significant effects on tissues. ${ }^{92}$

In short, light absorption depending on the wavelength, causes primary reactions on the mitochondria. These are followed by a cascade of secondary reactions (photosignal transduction and amplification) that occur in the cytoplasm, membrane and nucleus as shown by the Karu model (Figure 3).

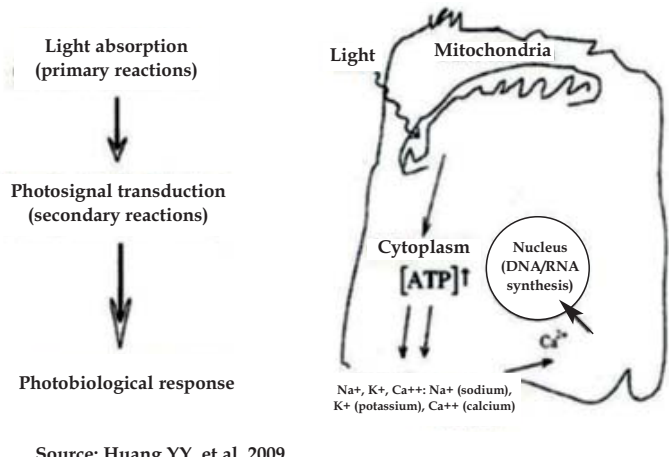

Figure 3: Karu Model

Nevertheless, there is a hypothesis about a modification in the Karu model. It is believed that the red light is absorbed by cytochrome-c oxidase inside the mitochondria, while the infrared wavelength is absorbed by specific cell membrane proteins directly affecting membrane permeability; both pathways lead to the same photobiological end response..$^{93}$

Sources like LASER differ from LED ones because of a characteristic known as coherence. This feature is related to stimulated emission mechanisms, with LASER light being formed by same frequency,

\section{REFERENCES}

1. Cesaretti IUR. Processo fisiológico de cicatrização da ferida. Pelle Sana. 1998;2:10-2.

2. Borges EL. Fatores intervenientes no processo de cicatrização. In: Borges EL, Saar SRC, Lima VLAN, Gomes FSL, Magalhães MBB. Feridas: como tartar. Belo Horizonte: Coopmed; 2001.

3. Mandelbaum SH, Di Santis EP, Mandelbaum MHS. Cicatrizacão: conceitos atuais e recursos auxiliaries - Parte II. An Bras Dermatol. 2003;78:525-42.

4. Poltawski L, Watson T. Transmission of therapeutic ultrasound by wound dressings. Wounds. 2007;19:1-12.

5. Cutting KF. Electric stimulation in the treatment of chronic wounds. Wounds. 2006;2:62-71.

6. Brem H, Kirsner RS, Falanga V. Protocol for the successful treatment of venous ulcers. Am J Surg. 2004;188:1-8.

7. Mester $E$, Juhász J, Varga P, Karika G. Lasers in clinical practice. Acta Chir Acad Sci Hung. 1968;9:349-57.

8. Yeh NG, Wu C, Cheng TC. Light-emitting diodes - their potential in biomedical applications. Renew Sust Energ Rev. 2010;14:2161-6.

9. Lubart R, Wollman Y, Friedmann H, Rochkind S, Laulicht I.. Effects of visible and near infrared lasers on cell cultures. J Photochem Photobiol B. 1992;12:305-10.

10. Yu W, Naim JO, Lanzafame RJ. Effects of photostimulation on wound healing in diabetic mice. Lasers Surg Med. 1997;20:56-63. direction and phase waves. ${ }^{94}$ Some authors believe that coherence plays a role in the production of light therapy derived benefits, and LED (not coherent) would be less efficient than LASER (coherent) or even unable to promote therapeutic effects. ${ }^{95}$

The reviewed studies, however, have shown that LED light can be as effective as LASER, since both have similar biological effects, with no significant difference between them. The cellular response to photostimulation is not associated with specific properties of LASER light, such as coherence. ${ }^{96}$ According to Karu, the property of coherence is lost during the interaction of light with biological tissue, not being thus a prerequisite for the process of photostimulation or photoinhibition. ${ }^{86}$

More clinical studies, especially with LEDs, must be performed in order to assess the adequacy of parameters commonly used experimental in vitro and animal studies to the clinical practice, since, in the relevant literature, there is a diversity in methodology, as well as differences in wavelength, dose and types of study.

\section{CONCLUSION}

The reviewed studies show that phototherapy, either by LASER or LED, is an effective therapeutic modality to promote healing of skin wounds. The biological effects promoted by these therapeutic resources are similar and are related to the decrease in inflammatory cells, increased fibroblast proliferation, angiogenesis stimulation, formation of granulation tissue and increased collagen synthesis. In addition to these effects, the irradiation parameters are also similar between LED and LASER. Importantly, the biological effects are dependent on such parameters, especially wavelength and dose, highlighting the importance of determining an appropriate treatment protocol. $\square$
11. Almeida-Lopes L, Rigau J, Zângaro RA, Guidugli-Neto J, Jaeger MM. Comparison of the low-level laser therapy effects on cultured human gingival fibroblasts proliferation using different irradiance and same fluence. Lasers Surg Med. 2001;29:179-84.

12. Reddy GK, Stehno-Bittel L, Enwemeka CS. Laser photostimulation accelerates wound healing in diabetic rats. Wound Repair Regen. 2001;9:248-55.

13. Pereira AN, Eduardo Cde P, Matson E, Marques MM. Effect of low-power laser irradiation on cell growth and procollagen synthesis of cultured fibroblasts. Lasers Surg Med. 2002;31:263-7.

14. Medrado AR, Pugliese LS, Reis SR, Andrade ZA. Influence of low level laser therapy on wound healing and its biological action upon myofibroblasts. Lasers Surg Med. 2003;32:239-44.

15. Pugliese LS, Medrado AP, Reis SR, Andrade Zde A. The influence of low level laser therapy on biomodulation of collagen and elastic fibers. Pesqui Odontol Bras. 2003;17:307-13.

16. Reddy GK. Comparison of the photostimulatory effects of visible He-Ne and infrared Ga-As lasers on healing impaired diabetic rat wounds. Lasers Surg Med. 2003:33:344-51.

17. Byrnes KR, Barna L, Chenault VM, Waynant RW, Ilev IK, Longo L, et al. Photobiomodulation improves cutaneous wound healing in an animal model of type II diabetes. Photomed Laser Surg. 2004;22:281-90. 
18. do Nascimento PM, Pinheiro AL, Salgado MA, Ramalho LM. A preliminary report on the effect of laser therapy on the healing of cutaneous surgical wounds as a consequence of an inversely proportional relationship between wavelength and intensity: histological study in rats. Photomed Laser Surg. 2004;22:513-8.

19. Ribeiro MS, Da Silva Dde F, De Araújo CE, De Oliveira SF, Pelegrini CM, Zorn TM, et al. Effects of low intensity polarized visible laser radiation on skin burns: a light microscopy study. J Clin Laser Med Surg. 2004;22:59-66.

20. Hawkins D, Abrahamse $\mathrm{H}$. Biological effects of Helium-Neon laser irradiation on normal and wounded human skin fibroblasts. Photomed Laser Surg. 2005;23:251-9.

21. Maiya GA, Kumar P, Rao L. Effect of low intensity Helium-Neon ( $\mathrm{He}-\mathrm{Ne})$ laser irradiation on diabetic wound healing dynamics. Photomed Laser Surg. 2005;23:187-90.

22. Moore P, Ridgway TD, Higbee RG, Howard EW, Lucroy MD. Effect of wavelength on low intensity laser irradiation stimulated cell proliferation in vitro. Lasers Surg Med. 2005;36:8-12.

23. Poon VKM, Huang L, Burd A. Biostimulation of dermal fibroblast by sublethal $Q$ switched Nd:YAG $532 \mathrm{~nm}$ laser: collagen remodeling and pigmentation. J Photochem Photobiol B. 2005:81:1-8

24. Carvalho PT, Mazzer N, dos Reis FA, Belchior AC, Silva IS.. Analysis of the influence of low power HeNe laser on the healing of skin wounds in diabetic and non-diabetic rats. Acta Cir Bras. 2006;21:177-83.

25. Hawkins D, Abrahamse $\mathrm{H}$. Effect of multiple exposures of low level laser therapy on the cellular responses of wounded human skin fibroblasts. Photomed Laser Surg. 2006;24:705-14.

26. Rabelo SB, Villaverde AB, Nicolau R, Salgado MC, Melo Mda S, Pacheco MT. Comparison between wound healing in induced diabetic and nondiabetic rats after low-level laser therapy. Photomed Laser Surg. 2006;24:474-9.

27. Araújo CEN, Ribeiro MS, Favaro R, Zezell DM, Zorn TMT. Ultrastructural and autoradiographical analyses show a faster skin repair in He-Ne laser-treated wounds. J Photochem Photobiol B. 2007;86:87-96.

28. Hawkins D, Abrahamse $\mathrm{H}$. Influence of broad-spectrum and infrared light in combination with laser irradiation on the proliferation of wounded skin fibroblasts. Photomed Laser Surg. 2007;25:159-69.

29. Houreld $\mathrm{N}$, Abrahamse $\mathrm{H}$. In vitro exposure of wounded diabetic fibroblast cells to a Helium-Neon laser at 5 and $16 \mathrm{~J} / \mathrm{cm} 2$. Photomed Laser Surg. 2007;25:78-84

30. Mirzaei M, Bayat M, Mosafa N, Mohsenifar Z, Piryaei A, Farokhi B, et al. Effect of low level laser therapy on skin fibroblasts of streptozotocin-diabetic rats. Photomed Laser Surg. 2007;25:519-25.

31. Rezende SB, Ribeiro MS, Nunez SC, Garcia VG, Maldonado EP. Effects of a single near infrared laser treatment on cutaneous wound healing: biometrical and histological study in rats. J Photochem Photobiol B. 2007;87:145-53.

32. Viegas VN, Abreu ME, Viezzer C, Machado DC, Filho MS, Silva DN, et al. Effect of low level laser therapy on inflammatory reactions during wound healing: comparison with meloxicam. Photomed Laser Surg. 2007;25:467-73.

33. Yasukawa A, Hrui H, Koyama Y, Nagai M, Takakuda K. The effect of low reactive level laser therapy (LLLT) with Helium-Neon laser on operative wound healing in a rat model. J Vet Med Sci. 2007:69:799-806.

34. Houreld NN, Abrahamse H. Laser light influences cellular viability and proliferation in diabetic wounded fibroblast cells in a dose and wavelength dependent manner. Lasers Med Sci. 2008;23:11-8.

35. Medrado AP, Soares AP, Santos ET, Reis SR, Andrade ZA. Influence of laser photobiomodulation upon connective tissue remodeling during wound healing. J Photochem Photobiol B. 2008:92:144-52.

36. Meireles GC, Santos JN, Chagas PO, Moura AP, Pinheiro AL. Effectiveness of lase photobiomodulation at 660 or 780 nanometers on the repair of third-degree burns in diabetic rats. Photomed Laser Surg. 2008;26:47-54.

37. Reis SR, Medrado AP, Marchionni AM, Figueira C, Fracassi LD, Knop LA. Effect of $670 \mathrm{~nm}$ laser therapy and dexamethasone on tissue repair: a histological and ultrastructural study. Photomed Laser Surg. 2008;26:307-13.

38. Gungormus M, Akyol UK. Effect of biostimulation on wound healing in diabetic rats. Photomed Laser Surg. 2009;27:607-10.

39. Skopin MD, Molitor SC. Effects of near infrared laser exposure in a cellular model of wound healing. Photodermatol Photoimmunol Photomed. 2009;25:75-80.

40. Carvalho PTC, Silva IS, Reis FA, Perreira DM, Aydos RD. Influence of ingaalp laser $(660 \mathrm{~nm})$ on the healing of skin wounds in diabetic rats. Acta Cir Bras. 2010:25:71-9.

41. Chung TY, Peplow PV, Baxter GD. Laser photobiostimulation of wound healing: defining a dose response for splinted wounds in diabetic mice. Lasers Surg Med. 2010:42:656-64.

42. Gonçalves RV, Novaes RD, Matta SL, Benevides GP, Faria FR, Pinto MV Comparative study of the effects of gallium-aluminum-arsenide laser photobiomodulation and healing oil on skin wounds in wistar rats: a histomorphometric study. Photomed Laser Surg. 2010;28:597-602.
43. Gonçalves RV, Mezêncio JM, Benevides GP, Matta SL, Neves CA, Sarandy MM, et al. Effect of gallium-arsenide laser, gallium-aluminum-arsenide laser and healing ointment on cutaneous wound healing in Wistar rats. Braz J Med Biol Res. 2010;43:350-5

44. de Oliveira Guirro EC, de Lima Montebelo MI, de Almeida Bortot B, da Costa Betito Torres MA, Polacow ML. Effect of laser $(670 \mathrm{~nm})$ on healing of wounds covered with occlusive dressing: a histologic and biomechanical analysis. Photomed Laser Surg. 2010;28:629-34.

45. Houreld N, Abrahamse $\mathrm{H}$. Low-intensity laser irradiation stimulates wound healing in diabetic wounded fibroblast cells (WS1). Diabetes Technol Ther. 2010;12:971-8.

46. Lacjaková K, Bobrov N, Poláková M, Slezák M, Vidová M, Vasilenko T, et al. Effects of equal daily doses delivered by different power densities of low-level laser therapy at $670 \mathrm{~nm}$ on open skin wound healing in normal and corticosteroid-treated rats: a brief report. Lasers Med Sci. 2010;25:761-6.

47. Medeiros JL, Nicolau RA, Nicola EM, dos Santos JN, Pinheiro AL. Healing of surgical wounds made with 1970-nm diode laser associated or not with laser phototherapy $(1655 \mathrm{~nm})$ or polarized light $(1400-2000 \mathrm{~nm})$. Photomed Laser Surg. 2010;28:489-96.

48. Hussein AJ, Alfars AA, Falih MA, Hassan AN. Effects of a low level laser on the acceleration of wound healing in rabbits. N Am J Med Sci. 2011;3:193-7.

49. Silveira PC, Silva LA, Freitas TP, Latini A, Pinho RA. Effects of low-power laser irradiation (LPLI) at different wavelengths and doses on oxidative stress and fibrogenesis parameters in an animal model of wound healing. Lasers Med Sci. 2011;26:125-31.

50. Weng Y, Dang Y, Ye X, Liu N, Zhang Z, Ren Q. Investigation of irradiation by different nonablative lasers on primary cultured skin fibroblasts. Clin Exp Dermatol. 2011;36:655-60.

51. Basso FG, Pansani TN, Turrioni AP, Bagnato VS, Hebling J, de Souza Costa CA. In vitro wound healing improvement by low-level laser therapy application in cultured gingival fibroblasts. Int J Dent. 2012;2012:719452.

52. Crisan B, Soritau O, Baciut M, Campian R, Crisan L, Baciut G. Influence of three laser wavelengths on human fibroblasts cell culture. Lasers Med Sci. 2013;28:457-63.

53. Dawood MS, Salman SD. Low level diode laser accelerates wound healing. Lasers Med Sci. 2013;28:941-5

54. Fahimipour F, Mahdian M, Houshmand B, Asnaashari M, Sadrabadi AN, Farashah $\mathrm{SE}$, et al. The effect of He-Ne and Ga-Al-As laser light on the healing of hard palate mucosa of mice. Lasers Med Sci. 2013;28:93-100.

55. Gonçalves RV, Novaes RD, Cupertino Mdo C, Moraes B, Leite JP, Peluzio Mdo C, et al. Time-dependent effects of low-level laser therapy on the morphology and oxidative response in the skin wound healing in rats. Lasers Med Sci. 2013;28:383-90.

56. Núñez SC, França CM, Silva DF, Nogueira GE, Prates RA, Ribeiro MS. The influence of red laser irradiation timeline on burn healing in rats. Lasers Med Sci. 2013:28:633-41.

57. Whelan HT, Smits RL Jr, Buchman EV, Whelan NT, Turner SG, Margolis DA, et al Effect of NASA light-emitting diode irradiation on wound healing. J Clin Laser Med Surg. 2001;19:305-14.

58. Vinck EM, Cagnie BJ, Cornelissen MJ, Declercq HA, Cambier DC. Green light emitting diode irradiation enhances fibroblast growth impaired by high glucose level. Photomed Laser Surg. 2005;23:167-71.

59. Weiss RA, McDaniel DH, Geronemus RG, Weiss MA. Clinical trial of a non-therma LED array for reversal of photoaging: clinical, histologic and surface profilometric results. Lasers Surg Med. 2005;36:85-91.

60. Huang PJ, Huang YC, Su MF, Yang TY, Huang JR, Jiang CP. In vitro observations on the influence of copper peptide aids for the LED photoirradiation of fibroblast collagen synthesis. Photomed Laser Surg. 2007;25:183-90.

61. Lanzafame RJ, Stadler I, Kurtz AF, Connelly R, Peter TA Sr, Brondon P, et al. Reciprocity of exposure time and irradiance on energy density during photoradiation on wound healing in a murine pressure ulcer model. Lasers Surg Med. 2007;39:534-42.

62. Dall Agnol MA, Nicolau RA, de Lima CJ, Munin E. Comparative analysis of coherent light action (laser) versus non-coherent light (light-emitting diode) for tissue repair in diabetic rats. Lasers Med Sci. 2009;24:909-16.

63. Tada K, Ikeda K, Tomita K. Effect of polarized light emitting diode irradiation on wound healing. J Trauma. 2009;67:1073-9.

64. Komine N, Ikeda K, Tada K, Hashimoto N, Sugimoto N, Tomita K. Activation of the extracellular signal-regulated kinase signal pathway by light emitting diode irradiation. Lasers Med Sci. 2010;25:531-7.

65. Meyer PF, Araújo HG, Carvalho MGF, Tatum BIS, Fernandes ICAG, Ronzio OA et al. Avaliação dos efeitos do LED na cicatrização de feridas cutâneas em ratos Wistar (Assessment of effects of LED on skin wound healing in Wistar rats). Fisioter Bras. 2010;11:428-32 
66. de Sousa AP, Santos JN, Dos Reis JA Jr, Ramos TA, de Souza J, Cangussú MC, et al. Effect of LED phototherapy of three distinct wavelengths on fibroblasts on wound healing: a histological study in a rodent model. Photomed Laser Surg. 2010;28:547-52.

67. Adamskaya N, Dungel P, Mittermayr R, Hartinger J, Feichtinger G, Wassermann K et al. Light therapy by blue LED improves wound healing in an excision model in rats. Injury. 2011;42:917-21.

68. Lim WB, Kim JS, Ko YJ, Kwon H, Kim SW, Min HK, et al. Effects of 635nm lightemitting diode irradiation on angiogenesis in CoCl2-exposed HUVECs. Lasers Surg Med. 2011;43:344-52.

69. Cheon MW, Kim TG, Lee YS, Kim SH. Low level light therapy by Red-Green-Blue LEDs improves healing in an excision model of Sprague-Dawley rats. Pers Ubiquit Comput. 2013;17:1421-8.

70. Fushimi T, Inui S, Nakajima T, Ogasawara M, Hosokawa K, Itami S. Green light emitting diodes accelerates wound healing: characterization of the effect and its molecular basis in vitro and in vivo. Wound Repair Regen. 2012;20:226-35

71. Vinck EM, Cagnie BJ, Cornelissen MJ, Declercq HA, Cambier DC. Increased fibroblast proliferation induced by light emitting diode and low power laser irradiation. Lasers Med Sci. 2003;18:95-9.

72. Corazza AV, Jorge J, Kurachi C, Bagnato VS. Photobiomodulation on the angiogenesis of skin wounds in rats using different light sources. Photomed Laser Surg. 2007;25:102-6.

73. Volpato LE, de Oliveira RC, Espinosa MM, Bagnato VS, Machado MA. Viability of fibroblasts cultured under nutritional stress irradiated with red laser, infrared laser, and red light-emitting diode. J Biomed Opt. 2011;16:075004.

74. Nishioka MA, Pinfildi CE, Sheliga TR, Arias VE, Gomes HC, Ferreira LM. LED (660 $\mathrm{nm}$ ) and laser (670 nm) use on skin flap viability: angiogenesis and mast cells on transition line. Lasers Med Sci. 2012;27:1045-50.

75. Oliveira Sampaio SC, de C Monteiro JS, Cangussú MC, Pires Santos GM, dos Santos MA, dos Santos JN, et al. Effect of laser and LED phototherapies on the healing of cutaneous wound on healthy and iron-deficient Wistar rats and their impact on fibroblastic activity during wound healing. Lasers Med Sci. 2013;28:799-806.

76. de Sousa AP, Paraguassú GM, Silveira NT, de Souza J, Cangussú MC, dos Santos $\mathrm{JN}$, et al. Laser and LED phototherapies on angiogenesis. Lasers Med Sci. 2013;28:981-7.

77. Dias IFL, Siqueira CPCM, Toginho Filho DO, Duarte JL, Laureto E, Lima FM et al. Efeitos da luz em sistemas biológicos. Semina. 2009;30:33-40.

78. Schindl A, Schindl M, Pernerstorfer-Schon H, Schindl L. Low-intensity laser therapy: a review. J Investig Med. 2000;48:312-26.

79. Schubert EF. Light emitting diodes. New York: Cambridge University Press; 2003.

80. Posten W, Wrone DA, Dover JS, Arndt KA, Silapunt S, Alam M. Low-level laser therapy for wound healing: mechanism and efficacy. Dermatol Surg. 2005;31:334-40.

81. Huang $\mathrm{Y}, \mathrm{Chen} \mathrm{ACH}$, Hamblin M. Low-level laser therapy: an emerging clinical paradigm. SPIE Newsroom. 2009;9:1-3.

82. Sommer AP, Pinheiro AL, Mester AR, Franke RP, Whelan HT. Biostimulatory windows in low-intensity laser activation: lasers, scanners, and NASA's light-emitting diode array system. J Clin Laser Med Surg. 2001;19:29-33.

83. Karu TI. Primary and secondary mechanisms of action of visible to near-IR radiation on cells. J Photochem Photobiol B. 1999;49:1-17.

84. Karu TI. Low-power laser therapy. In: Vo-Dinh T. Biomedical photonics handbook. Florida: CRC Press; 2003

85. Karu TI, Kolyakov SF. Exact action spectra for cellular responses relevant to phototherapy. Photomed Laser Surg. 2005;23:355-61.

86. Karu TI. Photobiological fundamentals of low-power laser therapy. IEEE J Quantum Electron. 1987;23:1703-17.

87. Karu TI. Molecular mechanism of the therapeutic effect of low intensity laser radiation. Lasers Life Sci. 1988;2:53-74.
88. Karu TI, Tiphlova OA, Matveyets YuA, Yartsev AP, Letokhov VS. Comparison of the effects of visible femtosecond laser pulses and continuous wave laser radiation of low average intensity on the clonogenicity of Escherichia coli. J Photochem Photobiol B. 1991;10:339-44

89. Karu TI, Andreichuk T, And Ryabykh T. Changes in oxidative metabolism of murine spleen following diode laser (660-950nm) irradiation: effect of cellular composition and radiation parameters. Lasers Surg Med. 1993;13:453-62.

90. Karu TI, Kalendo GS, Letokhov VS. Control of RNA synthesis rate in tumor cells HeLa by action of low-intensity visible light of copper laser. Lett Nuov Cim. 1981;32:55-9.

91. Karu TI, Pyatibrat LV, Afanasyeva NI. Cellular effects of low power laser therapy can be mediated by nitric oxide. Lasers Surg Med. 2005;36:307-14.

92. Karu TI. The science of low-power laser therapy. Amsterdam: Gordon \& Breach Science; 1998.

93. Ribeiro MS, Zezell DMP. Laser de baixa intensidade (Low intensity laser). In: Gutknecht N, Eduardo CP. A Odontologia e o laser - Atuação do laser na especialidade odontológica (Dentistry and laser: laser action in an odontological specialty). São Paulo: Quintessence Editora; 2004.

94. Nussbaum EL, Baxter GD, Lilge L. A review of laser technology and light-tissue interactions as a background to therapeutic applications of low intensity lasers and other light sources. Phys Ther Rev. 2003;8:31-44.

95. Viera Alemán C, Purón E, Hamilton ML, Santos Anzorandia C, Navarro A, Pineda Ortiz I. Evaluation of motor and sensory neuroconduction of the median nerve in patients with carpal tunnel syndrome treated with non-coherent light emitted by gallium arsenic diodes. Rev Neurol. 2001;32:717-20.

96. Enwemeka CS. The place of coherence in light induced tissue repair and pain modulation. Photomed Laser Surg. 2006;24:457.

\author{
MAILING ADDRESS: \\ Maria Emília de Abreu Chaves \\ Laboratório de Bioengenharia - Departamento de \\ Engenharia Mecânica \\ Universidade Federal de Minas Gerais \\ Avenida Presidente Antônio Carlos, 6627 - Pampulha \\ 31270-901 - Belo Horizonte - MG \\ Brazil \\ E-mail: mariaemilia.ufmg@gmail.com
}

How to cite this article: Chaves MEA, Araújo AR, Piancastelli ACC, Pinotti M. Effects of low-power light therapy on wound healing: LASER x LED. An Bras Dermatol. 2014;89(4):616-23. 